\title{
Schiff Base-Pd(II) Complexes Containing Pyridine and Thiophene Rings: Synthesis, Characterization, Suzuki- Miyaura C-C Coupling Reactions
}

\author{
Kenan Buldurun ${ }^{1}$ (D) Metin Ozdemir ${ }^{2}$
}

${ }^{1}$ Mus Alparslan University, Department of Food Processing, Mus, Turkey

${ }^{2}$ Mus Alparslan University, Department of Chemistry, Mus, Turkey

\section{A BS T RACT}

$\mathrm{N}$ ew Schiff base-palladium(II) complexes (1a-d) were synthesized with the reaction of Schiff base ligand and $\left[\mathrm{PdCl}_{2}\left(\mathrm{CH}_{3} \mathrm{CN}\right)_{2}\right]$. Pd(II) complexes (1a-d) were solid and stable to moisture and air. Their structures were characterized through the spectroscopic techniques including microanalysis, FT-IR, UV-Vis, proton $\left({ }^{1} \mathrm{H}\right)$ and carbon $\left({ }^{13} \mathrm{C}\right)$ NMR, mass spectrometry. The data obtained from the spectroscopic techniques showed that Schiff base-Pd(II) complexes $1 \mathrm{a}, 1 \mathrm{~b}$ and $1 \mathrm{c}$ were formed through the coordination of azomethine nitrogen and carbonyl/hydroxyl oxygen atoms, while 1d complex coordinated only azomethine nitrogen atom of the Schiff base. All complexes were found to have square plane. In addition, Pd(II) complexes (1a-d) were investigated in Suzuki-Miyaura coupling reactions of different aryl bromides using phenylboronic acid. The reactions were carried out in a mixed aqueous $\mathrm{EtOH} / \mathrm{H}_{2} \mathrm{O}(1 / 3)$ at room temperature with $\mathrm{K}_{2} \mathrm{CO}_{3}$ as the base for 1 hour. The Pd(II) complexes (1a-d) used as catalysts exhibited perfect catalytic activity in the Suzuki-Miyaura reaction.

Keywords:

Aryl bromides; Pd(II) complexes; Schiff base; Suzuki-Miyaura; Mass spectrometry.

\author{
Article History: \\ Received: 2019/10/01 \\ Accepted: 2019/12/09 \\ Online: 2019/12/31
}

\author{
Correspondence to: Kenan Buldurun, Mus \\ Alparslan University, Food Processing, \\ 49250, MUs, TURKEY \\ E-Mail:k.buldurun@alparslan.edu.tr \\ Phone: +904362494949 \\ Fax: +904362491318
}

\section{INTRODUCTION}

chiff bases are a multinucleated ligand group that $\checkmark$ forms complexes with many metal atoms through donor atoms. They have been extensively studied due to their important properties such as easy accessibility, low cost, selectivity and sensitivity to central metal ions [1-6]. Schiff base complexes exhibit high catalytic activities for a wide range of chemical reactions (e.g., hydrosilylation, homogenous catalyst, transfer hydrogenation, $\mathrm{C}-\mathrm{C}$ coupling reactions and epoxidation) [7-9]. The Suzuki-Miyaura reaction, which is one of the present C-C cross-coupling reactions, is the most important reaction between aryl halides and arylboronic acids and widely used to obtain biaryls. The Suzuki-Miyaura coupling reaction has been extensively studied in the field of synthesis owing to its ease of operation, perfect functional group compatibility, attainable and environmental friendly properties of the initial reagents. Due to their superior properties, biaryls is a widely preferred compound in numerous industrial applications such as pharmaceuticals, natural products, agrochemicals, advanced materials, cosmetics [10-17].
In the last decade, the synthesis of Schiff base$\mathrm{Pd}(\mathrm{II})$ complexes has gained great attention since they are cost-effective and environmentally friendly. Particularly, the studies on the catalytic application of Schiff base-Pd(II) complexes, which do not contain phosphine ligands, have increased in Heck-Mizoroki and Suzuki-Miyaura coupling reactions. The research on the synthesis and catalytic activities of Schiff bases and their transition metal complexes has been ongoing $[15,18]$.

In this article, four Schiff base-palladium complexes (1a-d) were prepared using $\left[\mathrm{PdCl}_{2}\left(\mathrm{CH}_{3} \mathrm{CN}\right)_{2}\right]$ metal salts, and their catalytic activities were investigated. The formation of $\mathrm{Pd}(\mathrm{II})$ complexes was determined through FT-IR, microanalysis, UV-Vis, ${ }^{1} \mathrm{H}$ and ${ }^{13} \mathrm{C}-\mathrm{NMR}$ and mass spectrometer. The catalytic activity of (1a-d) complexes was examined in the Suzuki-Miyaura carbon-carbon coupling reaction. Pd(II) complexes showed excellent activity as catalysts in the Suzuki-Miyaura coupling reaction. 

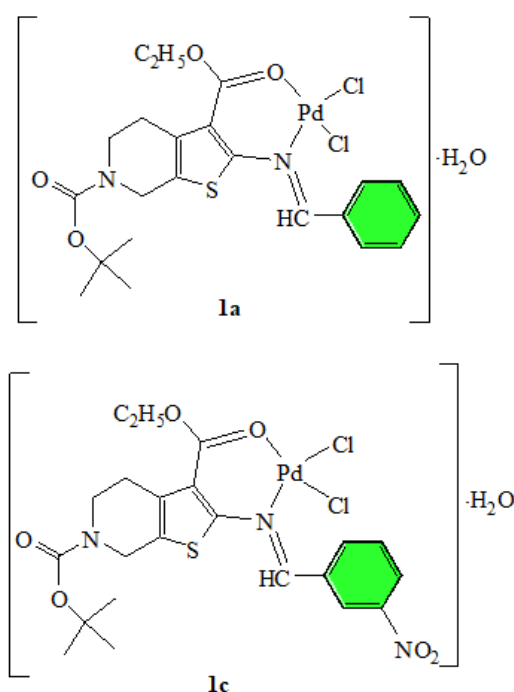

lc

Figure 1. Synthesis of Schiff base-Pd(II) complexes (1a-d)

\section{MATERIAL AND METHODS}

\section{Material and physical measurements}

FT-IR spectra were performed in the range of 400-4000 $\mathrm{cm}^{-1}$ on a Perkin Elmer 65 spectrometer. UV-Vis spectra were performed in the range of 200-800 nm (in EtOH) on a Shimadzu-1800 spectrophotometer. Mass spectra of the complexes were measured on an Agilent 1100 MSD spectrophotometer. The NMR $\left({ }^{1} \mathrm{H}\right.$ and $\left.{ }^{13} \mathrm{C}\right)$ spectra were determined with a Brucker $300 \mathrm{MHz}$ and $75 \mathrm{MHz}$. Microanalysis of $\mathrm{C}, \mathrm{H}, \mathrm{N}$ and $\mathrm{S}$ were determined on a CHNS-932 LECO instrument. The catalytic conversions were performed with GC-MS analysis by Agilent 7890B GC system and 5977MSD instrument. All reagents and solvents utilized were of commercial grade and without purified. All reactions were prepared under atmospheric condition.

\section{Synthesis of Schiff base-Pd(II) Complexes (1a-d)}

The 1a complex was prepared in $20 \mathrm{~mL}$ of methanol through the reaction of (E)-6-tert-butyl 3-ethyl 2 -(benzylideneamino)-4,5-dihydrothieno[2,3-c] $\left[\mathrm{PdCl}_{2}\left(\mathrm{CH}_{3} \mathrm{CN}\right)_{2}\right]$ (0.31 g; $\left.1.2 \mathrm{mmol}\right)$. The mixture was stirred at boiling temperature for one day, and the solvent was completely evaporated in a vacuum. The product was crystallized from a dichloromethane/diethyl ether (1:3) mixture. The proposed structure for the $\mathrm{Pd}(\mathrm{II})$ complex is given in Fig. 1. The other three complexes $\mathbf{1 b}$, 1c, 1d were prepared following the same procedure as for the complex 1a.

Anal. cald. for $\mathrm{C}_{22} \mathrm{H}_{28} \mathrm{~N}_{2} \mathrm{O}_{5} \mathrm{SPdCl}_{2}$ (\%): C, 43.35; H, 4.59, pyridine-3,6(7H)-dicarboxylate $(0.5 \mathrm{~g} ; 1.2 \mathrm{mmol})$ and<smiles>CCCOC(=O)c1c(-n2ccc3ccccc3o[Z9]2(O)Cl)sc2c1CCN(C(=O)OC(C)(C)C)C2</smiles>

$1 \mathbf{b}$<smiles>CCCOC(=O)c1c(N(/C=C/c2ccccc2OC)[Z1](O)(Cl)Cl)sc2c1CCN(C(=O)OC(C)(C)C)C2</smiles>

ld
N, 4.59; S, 5.25. Found: C, 43.40; H, 4.66; N, 4.65; S, 5.32. IR $\left(\mathrm{KBr}, \mathrm{cm}^{-1}\right)$ : $3426(-\mathrm{OH}), 3043$ (Ar-H), 2979 (Al-H), 1679 $(\mathrm{C}=\mathrm{O}), 1578$ (CH=N), 1577, 1491 (Ar-C), 781 (C-S-C), 554, 525 (M-O), 503, 491 (M-N). ${ }^{1} \mathrm{H}-\mathrm{NMR}\left(300 \mathrm{MHz}, \mathrm{DMSO}-\mathrm{d}_{6}\right.$, ppm): 8.10 (s, $1 \mathrm{H}, \mathrm{CH}=\mathrm{N}), 7.81-7.49$ (m, 5H, ArH), 4.35, 4.20 (m, 4H, $-2 \mathrm{CH}_{2}$ ), 3.80-3.11 (m, 4H, $\mathrm{CH}_{2}$ (pyridine)), 1.36, 1.20 (d, $\left.12 \mathrm{H},-\mathrm{CH}_{3}\right) .{ }^{13} \mathrm{C}-\mathrm{NMR}\left(75 \mathrm{MHz}, \mathrm{DMSO}-\mathrm{d}_{6}\right.$, ppm): 158.00, $155.00(2 \mathrm{C}=\mathrm{O}), 163.00(\mathrm{CH}=\mathrm{N}), 136.00-130.00$ (thiophenyl), 134.00-127.00 (benzene ring), 79.80 (tert-butyl), 58.96, 14.00 (-OC $\left.{ }_{2} \mathrm{H} 5\right), 43.00,18.00$ (pyridine), $\left.24.01\left(\mathrm{C} \mathrm{CH}_{3}\right)_{3}\right)$. UV-Vis. $\left(\lambda_{\max }, \mathrm{nm}\right): \pi \rightarrow \pi^{*}, 217,225,233 ; \mathrm{n} \rightarrow \pi^{*}, 302,384$. LC-MS:

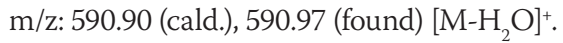

Complex 1b: Anal. cald. for $\left(\mathrm{C}_{22} \mathrm{H}_{27} \mathrm{~N}_{2} \mathrm{O}_{6} \mathrm{SPdCl}\right)$ (\%): C, 44.83; H, 4.58; N, 4.75; S, 5.43. Found: C, 44.81; H, 4.56; N, 4.62; S, 5.46. IR (KBr, cm $\left.{ }^{-1}\right): 3506,3442(-\mathrm{OH}), 3020(\mathrm{Ar}-\mathrm{H})$, 2977 (Al-H), $1685(\mathrm{C}=\mathrm{O}), 1605(\mathrm{CH}=\mathrm{N}), 1572,1521$ (ArC), 1151 (C-O), 760 (C-S-C), 565, 550 (M-O), 463 (M-N). ${ }^{1} \mathrm{H}-\mathrm{NMR}$ (300 MHz, DMSO-d $\left.{ }_{6}, \mathrm{ppm}\right): 8.80\left(\mathrm{~s},{ }^{1} \mathrm{H}, \mathrm{CH}=\mathrm{N}\right)$, 7.69-6.97 (m, 4H, ArH), 4.54, 4.40 (m, 4H, $\left.-2 \mathrm{CH}_{2}\right), 3.35-2.51$ (m, 4H, $\mathrm{CH}_{2}$ (pyridine)), 1.46-1.26 (d, 12H, - CH3). ${ }^{13} \mathrm{C}-\mathrm{NMR}$ (75 MHz, DMSO-d, ppm): 162.70, 154.24 (2C=O), 161.61 $(\mathrm{CH}=\mathrm{N}), 133.00-129.00$ (thiophenyl), 136.00, 117.00 (benzene ring), 80.00 (tert-butyl), 61.07, $14.59\left(-\mathrm{OC}_{2} \mathrm{H}_{5}\right), 44.02$, 18.00 (pyridine), $28.51\left(\mathrm{C}\left(\mathrm{CH}_{3}\right)_{3}\right)$. UV-Vis. $\left(\lambda_{\max }, \mathrm{nm}\right): \pi \rightarrow \pi^{*}$, 221; $\mathrm{n} \rightarrow \pi^{*}, 301$, 391, 504. LC-MS: m/z: 553.42 (cald.), 553.17 (Found) $[\mathrm{M}-\mathrm{Cl}]^{+}$.

Complex 1c: Anal. cald. for $\left(\mathrm{C}_{22} \mathrm{H}_{27} \mathrm{~N}_{3} \mathrm{O}_{7} \mathrm{SPdCl}_{2}\right)$ (\%): C, 40.34; H, 4.12; N, 6.42; S, 4.89. Found: C, 40.31; H, 4.17; $\mathrm{N}, 6.49 ; \mathrm{S}, 5.01$. IR (KBr, cm $\left.\mathrm{cm}^{-1}\right): 3434(-\mathrm{OH}), 3051(\mathrm{Ar}-\mathrm{H})$, 2982 (Al-H), 1682 (C=O), 1580 (CH=N), 1531, 1467 (Ar-C), 1385 (C-NO $\left.{ }_{2}\right), 781$ (C-S-C), 556, 516 (M-O), 493, 467 (M-N). ${ }^{1} \mathrm{H}-\mathrm{NMR}$ (300 MHz, DMSO-d, $\left.\mathrm{ppm}\right): 8.32$ (s, 1H, CH=N), 7.50-7.01 (m, 4H, Ar-H), 5.76, 4.19 (m, 4H, $\left.-2 \mathrm{CH}_{2}\right), 3.35-2.80$ 
Table 1. Optimization of the reaction conditions for Suzuki coupling reaction.

\begin{tabular}{|c|c|c|c|}
\hline Entry & Base & Time (h) & Yield (\%) \\
\hline 1 & $\mathrm{NOH}$ & 8 & 64 \\
\hline 2 & $\mathrm{CS}_{2} \mathrm{CO}_{3}$ & 8 & 51 \\
\hline 3 & $\mathrm{KOH}$ & 8 & 67 \\
\hline 4 & $\mathrm{~K}_{2} \mathrm{CO}_{3}$ & 8 & 95 \\
\hline 5 & $K O B u^{t}$ & 8 & 68 \\
\hline 6 & - & 8 & - \\
\hline 7 & $\mathrm{~K}_{2} \mathrm{CO}_{3}$ & 1 & 95 \\
\hline
\end{tabular}

(m, 4H, $\mathrm{CH}_{2}$ (pyridine)), 1.69-1.21 (d, $\left.12 \mathrm{H},-\mathrm{CH}_{3}\right) \cdot{ }^{13} \mathrm{C}-\mathrm{NMR}$ (75 MHz, DMSO-d, ppm): 165.00, $163.00(2 \mathrm{C}=\mathrm{O}), 159.30$ $(\mathrm{CH}=\mathrm{N}), 134.00-129.94$ (thiophenyl), 129.00, 108.00 (benzene ring), 94.47 (tert-butyl), 59.50, $14.84\left(-\mathrm{OC}_{2} \mathrm{H}_{5}\right), 47.00$, 15.16 (pyridine), $29.16\left(\mathrm{C}\left(\mathrm{CH}_{3}\right)_{3}\right)$. UV-Vis. $\left(\lambda_{\max }, \mathrm{nm}\right): \pi \rightarrow \pi^{*}$, 226; $\mathrm{n} \rightarrow \pi^{*}, 309,343,362$. LC-MS: m/z: 652.90 (Cald.), 652.73 (Found) $[\mathrm{M}-\mathrm{H}]$.

Complex 1d: Anal. cald. for $\left(\mathrm{C}_{23} \mathrm{H}_{30} \mathrm{~N}_{2} \mathrm{O}_{6} \mathrm{SPdCl}_{2}\right)$ (\%): C, 43.17; H, 4.69; N, 4.37; S, 5.00. Found: C, 43.13; H, 4.70; $\mathrm{N}, 4.38 ; \mathrm{S}, 5.16$. IR $\left(\mathrm{KBr}, \mathrm{cm}^{-1}\right): 3445(-\mathrm{OH}), 3060(\mathrm{Ar}-\mathrm{H})$, 2978 (Al-H), 1683 (C=O), $1583(\mathrm{CH}=\mathrm{N}), 1533$ (Ar-C), 1247 $\left(-\mathrm{OCH}_{3}\right), 757$ (C-S-C), 573, 510 (M-O), 487 (M-N). ${ }^{1} \mathrm{H}-\mathrm{NMR}$ (300 MHz, DMSO-d, $\mathrm{ppm}): 8.68(\mathrm{~s}, 1 \mathrm{H}, \mathrm{CH}=\mathrm{N}), 7.95$ $6.90(\mathrm{~m}, 4 \mathrm{H}, \mathrm{ArH}), 5.37,4.32\left(\mathrm{~m}, 4 \mathrm{H},-2 \mathrm{CH}_{2}\right), 3.97-2.42(\mathrm{~m}$, $4 \mathrm{H}, \mathrm{CH}_{2}$ (pyridine)), $1.28-1.22$ (d, $\left.12 \mathrm{H},-\mathrm{CH}_{3}\right) .{ }^{13} \mathrm{C}-\mathrm{NMR}$ (75 MHz, DMSO-d, ppm): 165.00, $161.00(2 \mathrm{C}=\mathrm{O}), 157.20$ $(\mathrm{CH}=\mathrm{N}), 134.00-120.10$ (thiophenyl), 128.70-111.00 (benzene ring), 77.24 (tert-butyl), 55.60, $14.47\left(-\mathrm{OC}_{2} \mathrm{H}_{5}\right), 53.44$ (pyridine), $28.70\left(\mathrm{C}\left(\mathrm{CH}_{3}\right)_{3}\right)$. UV-Vis. $\left(\lambda_{\max }, \mathrm{nm}\right): \pi \rightarrow \pi^{*}, 205$, 215, 251; $\rightarrow \pi^{*}$, 315, 398. LC-MS: $\mathrm{m} / \mathrm{z}: 550.89$ (Cald.), 550.99 (Found) $[\mathrm{M}-\mathrm{Cl} 2, \mathrm{H} 2 \mathrm{O}]^{2+}$.

Table 2. Optimization of the reaction conditions for Suzuki coupling reaction.

\begin{tabular}{cccc}
\hline Entry & Solvent & Time $(h)$ & Yield (\%) \\
\hline 1 & Ethanol & 10 & 72 \\
2 & Methanol & 10 & 60 \\
3 & Acetonitrile & 10 & 35 \\
4 & Tolvene & 10 & 52 \\
5 & DMF & 10 & 41 \\
6 & THF & 10 & 39 \\
7 & Dioxane & 10 & 41 \\
8 & i-PrOH $+\mathrm{H}_{2} \mathrm{O}$ & 10 & 76 \\
9 & EtOH $+\mathrm{H}_{2} \mathrm{O}$ & 1 & 95 \\
\hline
\end{tabular}

${ }^{1}$ Reaction conditions: Phenyl boronic acid $(3.0 \mathrm{mmol})$, aryl bromide (2.0 $\mathrm{mmol})$, base $(4.0 \mathrm{mmol})$, catalyst $(0.01 \mathrm{mmol})$, solvent $(5 \mathrm{~mL})$ and $25^{\circ} \mathrm{C}$.

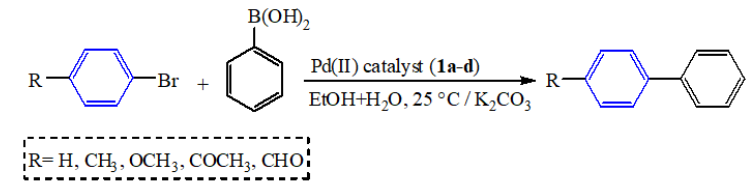

Figure 2. Suzuki-Miyaura cross-coupling reaction.

\section{Catalytic Activity of Pd(II) Complexes for Suzuki- Miyaura Cross-Coupling Reaction}

Suzuki-Miyaura cross-coupling is a reaction with palladium-catalyzed aryl and vinyl halide-containing aryl or vinyl boronic acid [19]. A reaction mixture of phenylboronic acid (3.0 $\mathrm{mmol})$, aryl bromide $(2.0 \mathrm{mmol})$, base $(4.0$ $\mathrm{mmol})$ and catalyst $(0.01 \mathrm{mmol})$ was mixed in $(\mathrm{EtOH} /$ $\left.\mathrm{H}_{2} \mathrm{O}\right)(1: 3)(5 \mathrm{~mL})$ at $25{ }^{\circ} \mathrm{C}$ for $1 \mathrm{~h}$ (Fig. 2). After the reaction completed, the mixture was extracted with ethyl acetate. The ethyl acetate solution was dried over $\mathrm{MgSO}_{4}$ and filtered to remove the trace water content. The ethyl acetate solution was passed through a silica column (60120 mesh), and there for impurities were removed. The yields were measured by GC-MS.

The optimization conditions were determined first during the experimental studies. In order to determine the appropriate base to be used in the Suzuki reaction, a reaction of p-bromoacetophenone and phenylboronic acid was performed in EtOH/H2O (1:3) mixture at $25{ }^{\circ} \mathrm{C}$ and atmospheric condition for $1 \mathrm{~h}$. Optimum conditions were formed using 1a complex as catalyst. Various bases such as $\mathrm{KOH}, \mathrm{NaOH}, \mathrm{KOBu}, \mathrm{K}_{2} \mathrm{CO}_{3}$ and $\mathrm{Cs}_{2} \mathrm{CO}_{3}$ were checked. The obtained results are given in Table 1 and Table 2.

\section{RESULTS AND DISCUSSION}

IR spectra of $\mathrm{Pd}(\mathrm{II})$ complexes (1a-d) showed that azomethine peaks shifted to a high or low area, unlike ligands. This indicated that the Pd metal was coordinated with the $\mathrm{N}$ atom of the azomethine group of ligands. In the complexes 1a and 1c, it was connected with carbonyl oxygen and supported by band shifts [15]. In the $\mathbf{1 b}$ complex, the absence of the peak of the $\mathrm{OH}$ group seen in the ligand and the shift in the $(\mathrm{C}-\mathrm{O})$ peak, unlike the ligand, indicated that there was coordination with the phenolic oxygen atom [16]. The new bands for all $\mathrm{Pd}(\mathrm{II})$ complexes (1a-d) in range of 573-510 $\mathrm{cm}^{-1}$ and 503-463 $\mathrm{cm}^{-1}$ suggested a coordination of the carbonyl/hydroxyl oxygen and azomethine nitrogen atom to the palladium, respectively [6, 17-19].

The ${ }^{1} \mathrm{H}-\mathrm{NMR}$ spectra of $\mathrm{Pd}(\mathrm{II})$ complexes (1a-d) showed signals 8.10, 8.80, 8.32, 8.68 ppm for azomethine $(-\mathrm{CH}=\mathrm{N}-)$ proton, respectively. For $\mathbf{1 b}$ complex, the phenolic $\mathrm{OH}$ proton disappeared because of the deprotonation of 
Table 3. Suzuki coupling reaction of various aryl bromide with phenylboronic acid

\begin{tabular}{|c|c|c|c|c|}
\hline Entry & $P d(I I)$ & Aryl Bromide & Temp $\left({ }^{\circ} \mathrm{C}\right)$ & Yield (\%) \\
\hline 1 & $1 a$ & \multirow{4}{*}{$\mathrm{Br} \longrightarrow$} & \multirow{4}{*}{25} & 95 \\
\hline 2 & $1 b$ & & & 96 \\
\hline 3 & $1 C$ & & & 98 \\
\hline 4 & $1 d$ & & & 98 \\
\hline 5 & $1 a$ & \multirow{4}{*}{$\mathrm{Br}-\mathrm{C}$} & \multirow{4}{*}{25} & 66 \\
\hline 6 & $1 b$ & & & 97 \\
\hline 7 & $1 C$ & & & 99 \\
\hline 8 & $1 d$ & & & 98 \\
\hline 9 & $1 a$ & \multirow{4}{*}{$\mathrm{Br} \longrightarrow$} & \multirow{4}{*}{25} & 93 \\
\hline 10 & $1 b$ & & & 95 \\
\hline 11 & $1 C$ & & & 96 \\
\hline 12 & $1 d$ & & & 96 \\
\hline 13 & $1 a$ & \multirow{4}{*}{$\mathrm{Br} \longrightarrow$} & \multirow{4}{*}{25} & 96 \\
\hline 14 & $1 b$ & & & 75 \\
\hline 15 & $1 c$ & & & 89 \\
\hline 16 & $1 d$ & & & 94 \\
\hline 17 & $1 a$ & & \multirow{4}{*}{25} & 100 \\
\hline 18 & $1 b$ & & & 100 \\
\hline 19 & $1 C$ & & & 100 \\
\hline 20 & $1 d$ & & & 73 \\
\hline
\end{tabular}

the ligand.

The ${ }^{13} \mathrm{C}-\mathrm{NMR}$ spectra resonance of azomethine $(-\mathrm{CH}=\mathrm{N}-$ ) carbon atom of $\mathrm{Pd}(\mathrm{II})$ complexes (1a-d) observed at 163.01, 161.61, 159.30, 157.20 ppm, respectively. This signal indicated coordination of azomethine nitrogen Pd atom [18-20].

The UV-Vis spectrum of the complexes (1a-d) exhibited the bands 205-251 nm, which might be attributed to $\pi \rightarrow \pi^{*}$ transition of the aromatic rings. The bands observed at 301-343 $\mathrm{nm}$ region might be attributed to $\mathrm{n} \rightarrow \pi^{*}$ transitions of the $\mathrm{C}=\mathrm{N}$ moiety. $\mathrm{Pd}(\mathrm{II})$ complexes (1a-d) showed a low energy band in the range of 504-343 nm for MLCT (metal to ligand charge transfer) transitions. These results may suggest that $\mathrm{Pd}(\mathrm{II})$ complexes had a square-planar geometry [6, 22-26].

Table 3 showed that the palladium complexes (1a-d) had a good activity in Suzuki-Miyaura C-C coupling reaction. It was seen that there was no precise ranking between the activities of the complexes. The catalytic activities of some complexes were observed to vary between $66-100 \%$, depending on the aryl bromides used (Table 3, entries 1-20). A yield of up to $100 \%$ was obtained with halogenated substrates bearing substituted groups attached to the aromatic ring. The activity of the bromoaryls used as the substrate appeared to vary from $p$-bromoacetophenone $>p$-bromoanisole $>p$-bromobenzene $>p$-bromoaldehyde $>p$-bromotoluene. This means that the catalytic activity of Pd(II) (1a-d) complexes were the highest in the case of p-bromoacetophenone, providing $95-98 \%$ conversion (Table 3, entries 1-4). It was found that both catalysts and aryl bromide were active in terms of structure.

In the present study, it was observed that the efficiency of catalytic transformations for all complexes did not change significantly depending on the substituting groups of Schiff base-Pd(II) complexes. The electronic parameters had no important effect on the catalytic conversion, but the steric effect of the groups present in the Schiff base structure significantly altered the activity of the complexes. In case of $p$-bromoaldehyde used as an aryl bromide, it provided a conversion between 66-98\% (Table 3, entries 5-8). In this study, it was found that the efficiency of catalytic transformations for all complexes varied depending on the substitu- 
ted groups of Schiff base-Pd(II) complexes. Electronic parameters of Schiff base ligands had a significant effect on the catalytic conversion. The absence of any groups attached to the benzene ring of the ligand resulted in a low yield of $66 \%$ in the 1a complex. Therefore, it was concluded that the catalysts significantly affected the activity of the electronic structures.

When $p$-bromoanisole was used as an aryl bromide, catalytic conversion of the (1a-d) complexes ranging from 93$96 \%$ was obtained in the rate of catalytic conversion (Table 1 , entries 9-12). When the catalytic transformations of the (1ad) complexes were evaluated, it was seen that the activity of the catalysts did not change due to the substituted groups of Schiff base-Pd(II) complexes and gave close results to each other. Although the electronic parameters did not have an important influence on the catalytic conversion, the steric effect changed the activity of the complexes significantly. Therefore, it was found that the groups in the Schiff base structure had a significant influence on the activity of the catalysts.

When $p$-bromotoluene was used as an aryl bromide, catalytic transformations ranging from $75-96 \%$ were obtained in the catalysis of 1a-d complexes (Table 1, entries 13-16). The assessment of the catalytic transformations of $\mathrm{Pd}(\mathrm{II})$ complexes (1a-d) showed that the activity of the catalysts did not change due to the substituting groups of Schiff base-Pd(II) complexes and gave similar results. The electronic parameters did not have an important impact on the catalytic conversion; however, the steric effect significantly changed the activity of the complexes. Pd(II) complex (1b) with $p$-bromotoluene was found to show the lowest rate of catalytic activity (Table 1, entry 14). This was due to the electron attracting -OH group in the structure of the $\mathbf{1 b}$ complex.

When $p$-bromobenzene was used as aryl bromide, a good catalytic conversion of $73-100 \%$ was achieved (Table 1 , entries 17-20). The catalytic transformations of 1a-d complexes indicated that the activity of the catalysts did not change due to the substituted groups of Schiff base-Pd(II) complexes (1a-d) and gave similar results. Although the electronic parameters had no significant impact on the catalytic conversion, the steric effect significantly influenced the activity of the complexes. 1d complex with p-bromobenzene was found to show a relatively low rate of catalytic activity (Table 1, entry 20). This was due to the electron-providing $-\mathrm{OCH}_{3}$ group in the structure of the $\mathbf{1 d}$ complex.

The Schiff base-Pd(II) complexes (1a-d) used in the Suzuki reaction yielded a good degree of catalytic conversion ranging from $66-100 \%$. At the same time, the structure and position of the ligand-bound substituted groups incre- ased their catalytic activity. It was found that the electronic structure of the Schiff base groups and the electronic effect of the substrate used did not significantly affect the activity of the catalysts. When the catalytic results of Pd(II) complexes were examined, it was observed that all complexes were active for Suzuki-Miyaura coupling reactions and formed active catalytic systems under optimum conditions. Pd(II) complexes (1a-d) were found to have a very good catalytic activity.

\section{CONCLUSION}

In this study, four new stable and easily soluble Schiff base-Pd(II) complexes (1a-d) containing thiophene and pyridine rings were synthesized. The structures were elucidated using different spectroscopic techniques. Spectroscopic data showed that the $\mathrm{Pd}(\mathrm{II})$ complexes had a square plane geometric structure. It was also found that Schiff base-Pd (II) complexes provided an excellent catalytic activity in the Suzuki-Miyaura coupling reaction. Pd(II) complexes (1a-d) occurred in the Suzuki coupling reactions in a short time and at low temperatures. Thus, it was concluded that the groups in the Schiff base structure had a significant effect on the activity of the catalysts.

\section{ACKNOWLEDGEMENT}

This study has been undertaken as part of a research project in Muş Alparslan University with a project number of "BAP-18-TBMY-4902-01". The authors would like to thank BAYPUAM (Scientific Research-Publication and Projects Research and Application Center) for their financial support.

\section{References}

1. Beigi Z, Kianfar AH, Farrokhpour H, Roushani M, Azarian MH, Mahmood WAK. Synthesis, characterization and spectroscopic studies of nickel(II) complexes with some tridentate ONN donor Schiff bases and their electrocatalytic application for oxidation of methanol. Journal of Molecular Liquids 249 (2018) 117-125.

2. Turan N, Buldurun K, Gündüz B, Çolak N. Synthesis and structures of $\mathrm{Fe}(\mathrm{II}), \mathrm{Zn}(\mathrm{II})$ and $\mathrm{Pd}(\mathrm{II})$ complexes with a Schiff base derived from methyl 2-amino-6-methyl-4,5,6,7-tetrahydrothieno[2,3-c] pyridine-3-carboxylate and comparison of their optical constants for different solvents and molarities. Journal of Nanoelectronics and Optoelectronics 12 (2017) 1028-1040.

3. Pratihar JL, Mandal P, Lai CK, Chattopadhyay S. Tetradentateamidoazo Schiff base $\mathrm{Cu}(\mathrm{II}), \mathrm{Ni}(\mathrm{II})$ and $\mathrm{Pd}(\mathrm{II})$ complexes: Synthesis, characterization, spectral properties, and applications to catalysis in $\mathrm{C}-\mathrm{C}$ coupling and oxidation reaction. Polyhedron 161 (2019) 317-324.

4. Muche S, Harms K, Biernasiuk A, Malm A, Popiołek L, Hordyjewska A, Olszewska A, Hołynska M. New Pd(II) Schiff base complexes derived from ortho-vanillin and L-tyrosine or L-glutamic acid: Synthesis, characterization, crystal structures and biological 
properties. Polyhedron 151 (2018) 465-477.

5. Buldurun K, Turan N, Çolak N, Özdemir İ. Schiff base and its Fe(II), $\mathrm{Zn}(\mathrm{II}), \mathrm{Ru}(\mathrm{II}), \mathrm{Pd}(\mathrm{II})$ complexes containing ONS donor atoms: Synthesis, characterization and catalytic studies. Dokuz Eylül Üniversitesi Mühendislik Fakültesi Fen veMühendislik Dergisi 21 (2019) 73-82.

6. Kumar SB, Solanki A, Kundu S. Copper(II) and palladium(II) complexes with tridentate NSO donor Schiff base ligand: Synthesis characterization and structures. Journal of Molecular Structure 1143 (2017) 163-167.

7. Ali OAM. Characterization, thermal and fluorescence study of $\mathrm{Mn}(\mathrm{II})$ and $\mathrm{Pd}(\mathrm{II})$ Schiff base complexes. Journal of Thermal Analysis and Calorimetry 128 (2017) 1579-1590.

8. Debono N, Iglesias M, Sanchez F. New Pyridine ONN-Pincer gold and palladium complexes: Synthesis, characterization and catalysis in hydrogenation, hydrosilylation and C-C cross-coupling reactions. Advanced Synthesis \& Catalysis 349 (2007) 2470-2476.

9. Patel MN, Dosi PA, Bhatt BS. Square planar palladium(II) complexes of bipyridines: Synthesis, characterization, and biological studies. Journal of Coordination Chemistry 65 (2012) 3833-3844.

10. Nandhini R, Venkatachalam G, Kumar MD, Jaccob M. Dinuclear $\mathrm{Pd}(\mathrm{II})$ complexes containing bis-O,N-bidentate Schiff base ligands: Synthesis, characterization, DFT study and application as SuzukiMiyaura coupling catalysts. Polyhedron 158 (2019) 183-192.

11. Das P, Linert W. Schiff base-derived homogeneous and heterogeneous palladium catalysts for the Suzuki-Miyaura reaction. Coordination Chemistry Reviews 311 (2016) 1-23.

12. Ozdemir İ, Çetinkaya B, Demir S, Gürbüz N. Palladium-catalyzed Suzuki-Miyaura reaction using saturated $\mathrm{N}$-heterocarbene ligands. Catalysis Letters 97 (2004) 37-40.

13. Baran NY, Baran T, Menteş A, Karakışla M, Saçak M. Highly effective and recoverable $\mathrm{Pd}$ (II) catalyst immobilized on thermally stable Schiff base polymer containing phenol group: Production, characterization and application in Suzuki coupling reactions. Journal of Organometallic Chemistry 866 (2018) 87-94.

14. Kalita M, Gogoi P, Barman P, Sarma B, Buragohain AK, Kalita RD A new series of $\mathrm{Ni}(\mathrm{II}), \mathrm{Cu}(\mathrm{II}), \mathrm{Co}(\mathrm{II})$ and $\mathrm{Pd}(\mathrm{II})$ complexes with an ONS donor Schiff base: Synthesis, crystal structure, catalytic properties and bioactivities. Polyhedron 74 (2014) 93-98.

15. Priyarega S, Raja DS, Babu SG, Karvembu R, Hashimoto T, Endo A, Natarajan K. Novel binuclear palladium(II) complexes of 2-oxoquinoline-3-carbaldehyde Schiff bases: Synthesis, structure and catalytic applications. Polyhedron 34 (2012) 143-148.

16. Amalina MT, Hadariah B, Karimah K, Nazihah WIW.Pd(II) Complexes with nitrogen-oxygen donor ligands: Synthesis, characterization and catalytic activity for Suzuki-Miyaura cross- coupling reaction. ASEAN Journal on Science and Technology for Development 31 (2014) 15-23.

17. Layek S, Anuradha, Angrahari B, Pathak DD. Synthesis and characterization of a new Pd(II)-Schiff base complex [Pd(APD)2]: An efficient and recyclable catalyst for Heck-Mizoroki and SuzukiMiyaura reactions. Journal of Organometallic Chemistry 846 (2017) 105-112.

18. León AD, Pons J, Antón JG, Solans X, Bardia MF, Ros J. Preparation, NMR studies and crystal structure of mononuclear and dinuclear $\mathrm{Pd}(\mathrm{II})$ and Pt(II) complexes that contain 1,2-bis[3-(3,5-dimethyl-1pyrazolyl)-2-thiapropyl]benzene. Polyhedron 26 (2007) 2921-2928.

19. Agrahari B, Layek S, Anuradha, Ganguly R, Pathak DD. Synthesis, crystal structures, and application of two new pincer type palladium(II)-Schiff base complexes in C-C cross-coupling reactions. Inorganica Chimica Acta 471 (2018) 345-354.

20. Hassana HMA, Saad EM, Soltan MS, Betiha MA, Butler IS, Mostafa IS. A palladium(II) 4-hydroxysalicylidene Schiff-base complex anchoredon functionalized MCM-41: An efficient heterogeneous catalyst for the epoxidation of olefins. Applied Catalysis A: General 488 (2014) 148-159.

21. Bon VV, Orysyk SI, Pekhnyo VI, Volkov SV. Square-planar 1:2 $\mathrm{Ni}(\mathrm{II})$ and $\mathrm{Pd}(\mathrm{II})$ complexes with different coordination mode of salicylaldehyde (4)-phenylthiosemicarbazone: Synthesis, structure and spectral properties. Journal of Molecular Structure 984 (2010) 15-22.

22. Anan NA, Hassan SM, Saad EM, Butler IS, Mostafa SI. Preparation, characterization and $\mathrm{pH}$-metric measurements of 4-hydroxysalicylidenechitosan Schiff-base complexes of $\mathrm{Fe}(\mathrm{III})$, Co(II), Ni(II), Cu(II), Zn(II), Ru(III), Rh(III), Pd(II) and $\mathrm{Au}(\mathrm{III})$. Carbohydrate Research 346 (2011) 775-793.

23. Turan N, Buldurun K, Çolak N, Özdemir İ. Preparation and spectroscopic studies of $\mathrm{Fe}(\mathrm{II}), \mathrm{Ru}(\mathrm{II}), \mathrm{Pd}(\mathrm{II})$ and $\mathrm{Zn}$ (II) complexes of Schiff base containing terephthalaldehyde and their transfer hydrogenation and Suzuki-Miyaura coupling reaction. Open Chemistry 17 (2019) 571-580.

24. Mohamed RG, Elantabli FM, Abdel Aziz AA, Moustafa H, El-Medani SM. Synthesis, characterization, NLO properties, antimicrobial, CT-DNA binding and DFT modeling of $\mathrm{Ni}(\mathrm{II})$, Pd(II), Pt(II), Mo(IV) and Ru(I) complexes with NOS Schiff base. Journal of Molecular Structure 1176 (2019) 501-514.

25. Zaghal HM, Qaseer HA. Complexes of palladium, platinum and rhodium with 2,2凹-biquinoline and 2-(2区-pyridyl)quinolone. Transition Metal Chemistry16 (1991) 39-44.

26. Zaghal MH, Bani Saeed MS, Abdel Hamid AAG, Ali BF. Substitution reactions of cis-dichloro(2,2区-biquinoline)palladium(II) with amino acids. Arabian Journal of Chemistry 10 (2017) S3920-S3928. 